\title{
Contamination of Heavy Metals, Source, Effects on Leaving Things and Different Remediation Techniques in Soil: A Review
}

\author{
Alemnesh Sisay \\ Department of Natural Resource Management, Holetta Agriculture Research Center, Holetta, Ethiopia \\ Email address: \\ sisayalemnesh@gmail.com \\ To cite this article: \\ Alemnesh Sisay. Contamination of Heavy Metals, Source, Effects on Leaving Things and Different Remediation Techniques in Soil: A \\ Review. American Journal of Nanosciences. Vol. 5, No. 4, 2019, pp. 67-75. doi: 10.11648/j.ajn.20190504.17
}

Received: November 1, 2019; Accepted: November 27, 2019; Published: December 5, 2019

\begin{abstract}
Different researches showed that contamination of heavy metals in soil has become more and more serious, which affects Both soil fertility degradation and detrimental to human health through food chain causing adverse effects on human health. The concentration of metals beyond Maximum Permissible Level (MCL) leads to number of nervous, cardiovascular, renal, neurological impairment as well as bone diseases and several other health disorders and also computed the macronutrient in the human body. Due to these it needs more attention towards the contamination area using either prevention or minimizing methods of the source of contamination. Different researches mentioned different remediation techniques which involve phytoremediation, lime, phosphates, and different biochar materials. Remediation mechanisms basically consist of two fundamental principles. The first is to completely remove contaminations from polluted area and the second is to transform these pollutants to harmless forms. The application of Biochar in soil makes dual purpose which ameliorating soil fertility and remediated heavy metal due to the content of different physicochemical properties. So in this paper, including source of heavy metal, effect of heavy metal in human, plant growth and soil microorganism and remediation technique of contaminated soil, reaction of biochar in soil and application of biochar in soil quality were discussed. Therefore this is particular importance as it indicates the value of biochar as alternative remediation and amendments to ameliorate soil nutrient and acid soils for smallscale farmers who cannot afford to regularly purchase lime and mineral fertilizers as compared to phytoremediation techniques. But phytoremediation wide scope of area use of plants to partially or substantially remediate selected contaminants in contaminated soil, sludge, sediment, groundwater, surface water, and wastewater.
\end{abstract}

Keywords: Contaminated Soil, Heavy Metal, Remediation, Biochar, Phytoremediation

\section{Introduction}

Soil contamination by heavy metals (HMs, e.g. $\mathrm{Pb}, \mathrm{As}, \mathrm{Cd}$, etc.) has become more and more serious, which not only makes the soil fertility degradation, crop yield and quality reduction, but also ultimately endangers human health through food chain causing adverse effects on human health [1]. Metal contaminated soil poses risks to humans and animals through the consumption of plants that have bioaccumulated toxic metals from contaminated soil [2]. The rate at which HMs, are accumulated in the soil depends on the physicochemical properties of the soil and the relative efficiency of crops to remove the metals from the soil. Excessive content of metals beyond Maximum Permissible
Level (MCL) leads to a number of nervous, cardiovascular, renal, neurological impairment as well as bone diseases and several other health disorders [3]. Owing to these different remediation techniques follow in order to control heavy metals contamination from soil using physically, chemically and biologically method such as lime, phosphate, silicate, chelating agents and so on. However, these soil conditioners all have issues that the fixation effect of HMs is unstable or new HMs are introduced [4]. But the use of biochar to remove toxic metals from the contaminated site is a promising technology for the remediation of contaminated soil since those remediation materials are new soil conditioner which has characteristics of strong remediation ability, high stability and environmental friendliness [5]. 
Other as one efficient, cost-effective and environmental friendliness is phytoremediation has been focused on extensive interest for the purification of heavy metals contaminated soil and water [6].

The term biochar refers to the thermal decomposition of any by-products that derived from various biomass residue obtained when plant or animal biomass is subjected to heat treatment in an oxygen-limited environment which possesses good pore structure, large specific surface area and a variety of surface oxygen-containing functional groups [7] and the excellent Physico-chemical characteristics of biochar is useful for adsorption and hold of HMs in soil, and when applied to soil as an amendment. It acts as a dual purpose such as retains nutrients for plant uptake, soil fertility, therefore, it could be a kind of soil conditioner with great application of view [4].

Biochar characteristics depend on biomass species and preparation conditions (such as pyrolysis temperature, residence time, pyrolysis atmosphere), which directly affect the remediation effect on soil heavy metals with biochar [8]. Therefore, this review discusses Sources of heavy metals, influence of heavy metal pollutions in soil, and leaving things, remediation techniques of HMs, Remediation technique of biochar and effect of biochar species, Pyrolysis temperature and amount of biochar addition on contaminated soil, outlined through a new Conceptual framework.

\section{Literature Review}

\subsection{Toxic Heavy Metals}

Mercury, arsenic, cadmium, chromium, and lead are able to convince toxicity even at lower levels of exposure are considered universal toxicants. These elements have no beneficial effects on humans, and there is no known homeostasis mechanism for them [9].

Mercury (Hg)

Mercury, considered the most toxic heavy metal, has become part of the environment due to anthropogenic activities including agriculture, municipal wastewater discharge, mining, ignition, and discharges of industrial wastewater [10]. Having different bioavailability and toxicities associated with them, it exists in nature as an elemental or metallic form, in inorganic salts, and as organomercurial compounds. Metallic mercury finds its entry into (1) air mainly through mining and burning processes; and to (2) water and soil through erosion of natural depots, discharges from industries and runoff from landfill sites. Inorganic mercury exists either as mercuric $\left(\mathrm{Hg}^{2+}\right)$ or mercurous $\left(\mathrm{Hg}^{+}\right)$form. Having greater solubility in water, their toxic consequences are much greater compared with the elemental $\mathrm{Hg}$ [11].

Arsenic (As)

Arsenic, a naturally occurring metalloid, has universal distribution in the environment. As may have several oxidation states (-III, 0, III and V). It is present in the soil and soil Solution as elemental, inorganic, and organic in large quantities all over the world makes it one of the most important metals, having adverse effects on the environment and human health (Such as $\mathrm{AsO} 4{ }^{3-}$ or $\mathrm{AsO} 3^{3-}$ ) [12]. As toxicity depends on its chemical form Pentavalent forms of As, which are dominant in aerobic conditions (e.g. arsenate $\mathrm{AsO} 4^{3-}$ ) are less toxic than trivalent compounds (e.g. arsenite). Having greater uptake and high affinity for sulfhydryl $(-\mathrm{SH})$ groups of proteins and enzymes, $\mathrm{As}^{\mathrm{III}}$ is considered more toxic than its counterpart, $\mathrm{As}^{\mathrm{V}}$ [13]. However, owing to its structural similarity to phosphate, $\mathrm{As}^{\mathrm{V}}$ exerts its toxicity through replacement of phosphate in different chemical reactions. As part of their toxicity, $\mathrm{As}^{\mathrm{V}}$ replaces the stable phosphodiester bond in ATP, thereby resulting in uncoupling of oxidative phosphorylation events and subsequent depletion of ATP stores, while depletion of the intermediate of Krebs cycle by $\mathrm{As}^{\mathrm{III}}$ results in the exhaustion of cellular energy via inhibition of cellular respiration [14].due to their significant toxicity, arsenic compounds are associated with a wide range of health problems ranging from gastrointestinal disturbance to development of neoplasms, particularly of the skin, liver, kidney, and lymphatic cancer [15]. Though short term exposure to low-level arsenic causes reduction in the production of erythrocytes and leukocytes, damage to blood vessels, nausea and vomiting, abnormal heartbeat, and pricking sensations in the hands and legs, its exposure for long time periods often leads to skin lesions, peripheral vascular disease, pulmonary disease and cardiovascular diseases, neurological problems, diabetes mellitus and certain types of cancers [16]. Chronic arsenicosis results in many irreversible changes in vital organs and a higher mortality rate. Despite the magnitude of this potentially lethal toxicity, there is no effective treatment for this disease. Existing in more than 200 different mineral forms, its availability as arsenate $\left(\mathrm{As}^{\mathrm{V}}\right.$ ) accounts for approximately $60 \%$, as sulfide or sulfosalt $20 \%$ and the remaining $20 \%$ in the form of arsenites, arsenides, oxides, silicates, and elemental arsenic [17]. Volcanic activity, weathering of rocks, geothermal waters, and forest fires constitute some of the natural sources of arsenic. In addition to pollution from natural sources, its applications in animal feed, glass and ceramics, herbicides, pesticides, wood preservatives, metallurgical operations, and many others contribute to its anthropogenic pollution. Humans generally encounter arsenic by natural as well as manmade sources through soil, water, air, and food [18].

Lead $(\mathrm{Pb})$

Lead $(\mathrm{Pb})$ is one of the most abundant natural substances on earth. Owing to its physical properties including low melting point and high malleability, it has widespread industrial use. In terms of usage, it ranks fifth on the list of metals [19]. Its use is associated with more than 900 industries, including mining, smelting, refining, battery manufacturing, and so on [20]. In addition to industry, it has applications in fertilizers and pesticides used for agriculture purposes, and in improving the octane rating of gasoline in vehicular traffic systems [21].

As a result of rapid industrialization, an increase in the 
effluent discharge from industrial units located in close proximity to rivers has resulted in an increase in its amount in water bodies. Along with this, application of sewage sludge directly or as part of irrigation from contaminated water bodies, as an exhaust product of leaded gasoline due to increased traffic activities in urban settings and increased use as part of fertilizers and pesticide for agricultural purposes has resulted in the pollution of soils, which has had a serious environmental impact [22].

Lead toxicity is a particularly insidious hazard with the potential to cause irreversible health effects. In the evaluation of its toxicity in humans, it was found that bone to blood mobilization increases during pregnancy, lactation, physiological stress, chronic disease, along with advanced age [23].

\subsection{Sources of Heavy Metals in Contaminated Soils}

The main sources of these metals are dust produced by energy, transport, metallurgy, production of construction materials; sanitary sewage, chemical wastewater, industrial mining wastewater, and urban mining mixed sewage; mining and industrial solid waste contamination; Fertilizers, pesticides, and mulch are important agricultural inputs for agricultural production materials at levels that are regarded as trace $\left(<1000 \mathrm{mg} \mathrm{kg}^{-1}\right)$ are toxic [24]. Due to the disturbance and acceleration of nature's slowly occurring geochemical cycle of metals by man, most soils of rural and urban environments may accumulate one or more of the heavy metals above defined background values high enough to cause risks to human health, plants, animals, ecosystems, or other media.

Fertilizers and pesticides

To grow and complete the life cycle, plants must acquire macronutrients $(\mathrm{N}, \mathrm{P}, \mathrm{K}, \mathrm{S}, \mathrm{Ca}$ and $\mathrm{Mg}$ ) and essential micronutrients. Large quantities of fertilizers are regularly added to soils in intensive farming systems to provide adequate $\mathrm{N}, \mathrm{P}$, and $\mathrm{K}$ for crop growth. The compounds used to supply these elements contain trace amounts of heavy metals (e.g., $\mathrm{Cd}$ and $\mathrm{Pb}$ ) as impurities, which, after continued fertilizer, the application may significantly increase their content in the soil [25]. Heavy metal content is relatively low in nitrogen and potash fertilizers, while phosphoric fertilizers usually contain considerable toxic heavy metals. Heavy metals in the compound fertilizers are mainly from master materials and manufacturing processes. The content of heavy metals in fertilizers is generally as follows: phosphoric fertilizer $>$ compound fertilizer $>$ potash fertilizer $>$ nitrogen fertilizer [26]. Cd is an important heavy metal contaminant in the soil. $\mathrm{Cd}$ is brought to soils with the application of phosphoric fertilizers. Accordingly, [27] studies showed that, with the application of a large number of phosphate fertilizers and compound fertilizers, the available content of $\mathrm{Cd}$ in soils increases constantly, $\mathrm{Cd}$ taken by plants increases.

Several common pesticides used fairly extensively in agriculture and horticulture in the past contained substantial concentrations of metals. For instance, in the recent past, about $10 \%$ of the chemicals have approved for use as insecticides and fungicides in UK were based on compounds that contain $\mathrm{Cu}, \mathrm{Hg}, \mathrm{Mn}, \mathrm{Pb}$, or $\mathrm{Zn}$. Such contamination has the potential to cause problems, particularly if sites are redeveloped for other agricultural or nonagricultural purposes. Compared with fertilizers, the use of such materials has been more localized, being restricted to particular sites or crops [28].

Bio-solids and Manures

The application of numerous biosolids (e.g., livestock manures, composts, and municipal sewage sludge) to land accidentally leads to the accumulation of heavy metals such as $\mathrm{As}, \mathrm{Cd}, \mathrm{Cr}, \mathrm{Cu}, \mathrm{Pb}, \mathrm{Hg}, \mathrm{Ni}, \mathrm{Se}, \mathrm{Mo}, \mathrm{Zn}, \mathrm{Sb}$, and so forth, in the soil [29]. Certain animal wastes such as poultry, cattle, and pig manures produced in agriculture are commonly applied to crops and pastures either as solids or slurries [30]. Although most manure is seen as valuable fertilizers, in the pig and poultry industry, the $\mathrm{Cu}$ and $\mathrm{Zn}$ added to diets as growth promoters and as contained in poultry health products may also have the potential to cause metal contamination of the soil [31]. The manures produced from animals on such diets contain high concentrations of $\mathrm{As}, \mathrm{Cu}$, and $\mathrm{Zn}$ and, if repeatedly applied to restricted areas of land, can cause a considerable buildup of these metals in the soil in the long run.

There is also considerable interest in the potential for composting biosolids with other organic materials such as sawdust, straw, or garden waste. If this trend continues, there will be implications for metal contamination of soils. The potential of biosolids for contaminating soils with heavy metals has caused great concern about their application in agricultural practices [32]. Heavy metals most commonly found in biosolids are $\mathrm{Pb}, \mathrm{Ni}, \mathrm{Cd}, \mathrm{Cr}, \mathrm{Cu}$, and $\mathrm{Zn}$, and the metal concentrations are governed by the nature and the intensity of the industrial activity, as well as the type of process employed during the biosolids treatment [33].

Wastewater

Worldwide, it is estimated that 20 million hectares of arable land are irrigated with wastewater. In several Asian and African cities, studies suggest that agriculture based on wastewater irrigation accounts for 50 percent of the vegetable supply to urban areas [34]. Farmers generally are not bothered about environmental benefits or hazards and are primarily interested in maximizing their yields and profits. Although the metal concentrations in wastewater effluents are usually relatively low, long-term irrigation of land with such can eventually result in heavy metal accumulation in the soil. Wastewater can be divided into several categories, sanitary sewage, chemical wastewater, industrial mining wastewater, and urban mining mixed sewage, etc. Heavy metals are brought to the soil by irrigation sewage and are fixed in the soil in different ways. It causes heavy metals $(\mathrm{Hg}, \mathrm{Cd}, \mathrm{Pb}, \mathrm{Cr}$, etc.) to continually accumulate in the soil year by year. Sewage irrigation is a feasible way to solve the problem of crop irrigation in the arid area. However, heavy metal contamination caused by sewage irrigation must be paid enough attention. The quality of irrigation sewage must be strictly controlled within the national quality standard for 
irrigation water [35].

Air-Borne Sources

Airborne sources of metals include stack or duct emissions of air, gas, or vapor streams, and fugitive emissions such as dust from storage areas or waste piles. Metals from airborne sources are generally released as particulates contained in the gas stream. Some metals such as $\mathrm{As}, \mathrm{Cd}$, and $\mathrm{Pb}$ can also volatilize during high-temperature processing. These metals will convert to oxides and condense as fine particulates unless a reducing atmosphere is maintained [36]. Stack emissions can be distributed over a wide area by natural air currents until dry and/or wet precipitation mechanisms remove them from the gas stream. Fugitive emissions are often distributed over a much smaller area because emissions are made near the ground. In general, contaminant concentrations are lower in fugitive emissions compared to stack emissions. The type and concentration of metals emitted from both types of sources will depend on sitespecific conditions. All solid particles in smoke from fires and in other emissions from factory chimneys are eventually deposited on land or sea; most forms of fossil fuels contain some heavy metals and this is, therefore, a form of contamination which has been continuing on a large scale since the industrial revolution began. For example, a very high concentration of $\mathrm{Cd}, \mathrm{Pb}$, and $\mathrm{Zn}$ has been found in plants and soils adjacent to smelting works.

\subsection{Effect of Heavy Metal Polluted Soil on Plant Growth}

The heavy metals that are available for plant uptake are those that are present as soluble components in the soil solution or those that are easily solubilized by root exudate. Although plants require certain heavy metals for their growth and upkeep, excessive amounts of these metals can become toxic to plants. The ability of plants to accumulate essential metals equally enables them to acquire other nonessential metals [37].

As metals cannot be broken down, when concentrations within the plant exceed optimal levels; they adversely affect the plant both directly and indirectly. Some of the direct toxic effects caused by high metal concentration include inhibition of cytoplasmic enzymes and damage to cell structures due to oxidative stress [38]. An example of indirect toxic effect is the replacement of essential nutrients at cation exchange sites of plants [39]. Further, the negative influence heavy metals have on the growth and activities of soil microorganisms may also indirectly affect the growth of plants. For instance, a reduction in the number of beneficial soil microorganisms due to high metal concentration may lead to a decrease in organic matter decomposition leading to a decline in soil nutrients. These toxic effects (both direct and indirect) lead to a decline in plant growth which sometimes results in the death of plants [40].

\subsection{Effects of Heavy Metals in Human Health}

Reported ways for the connection of heavy metals to the human body comprises direct breathing of polluted air, drinking of polluted water and direct contact with soil and ingestion of food comprising of plants developed in metalpolluted soil [41]. Heavy metal-polluted food can severely reduce some vital nutrients in the body that are accountable for declining immunological defenses, growth delay, reduced psychosocial abilities, incapacities related to malnutrition and greater occurrence of upper gastrointestinal cancer degrees [42]. Metals are non-decomposable and are recognized as main environmental contaminants causing cytotoxic, mutagenic and cancerous (carcinogenic) effects in animals [43]. The biotic half-lives of these heavy metals are lengthy and furthermore, these have capacity to store in various organs of the body and therefore result in annoying side effects [44].

\subsection{Remediation Technique of Heavy Metals in Contaminated Soil}

The term remediation is the processes or methods for treating a contaminated media in the environment in a way that they are contained, removed or degraded. Remedial actions should be taken when a risk assessment indicates a high and unacceptable level of risk. Moreover, if there is evidence of environmental and human harm or if the limits for contaminants in food, water, and soil are exceeded, remedial actions should be taken. Remediation methods of contaminated soils with heavy metals can be generally classified into physical, chemical and biological (phytoremediation) [45]. Remediation mechanisms basically consist of two fundamental principles. The first is to completely remove contaminations from polluted area and the second is to transform these pollutants to harmless forms by using one or more engineering technologies and immobilization form, which mainly include excavation, separation, extraction, electrokinesis, washing, oxidation, reduction, phytoextraction, phytovolatilization, or solidification, verification, ion exchanging, complexation and others [45].

\subsubsection{Chemical Method of Remediation}

One of the chemical remediation strategies is soil stabilization of heavy metals. Stabilization involves adding different substances to soils, which adsorb, co-precipitate or in other ways bind heavy metals using biochar materials; chelating agents, lime, phosphates and so on. Due to these processes the mobility of contaminants decreases and hence, the contaminants are not available for plant uptake and do not leach to groundwater

(i). Biochar

Biochar is one organic material that is currently being subjugated for its potential in the management of heavy metal polluted soils. Literature reports showed a reduction in the availability of heavy metals when the polluted soil was amended with biochar; this, in turn, reduced plant absorption of the metals [46]. The use of biochar is dual purpose not only stabilization of heavy metals and also ameliorating soil nutrient availability of plant growth (like improvement of soil organic matter content, the increase of nitrogen, potassium, 
and other nutrients contents, utilization rate, and the improvement of soil erosion and acid soil) [47]. To retain nutrients for plant uptake and soil fertility, the infiltration of harmful quantities of nutrients and pesticides into groundwater and soil erosion runoff into surface waters can be limited with the use of biochar [48], enrich plant growth and yield [49], and reduce greenhouse gas emissions through $\mathrm{C}$ sequestration [50]. The ability of biochar to increase soil $\mathrm{pH}$ unlike most other organic amendments [51] may have increased the sorption of these metals, thus reducing their bioavailability for plant uptake. It is important to note that, since the characteristics of biochar vary widely depending on its method of production and the feedstock type used in its production, the effect different biochar amendments will have on the stabilization of heavy metals in soil will also differ.

(ii). Preparation of biochar

Biochar is produced by (1) Pyrolysis, (2) hydrothermal carbonization (HTC) and (3) microwave carbonization. Different preparation methods affect the physical and chemical properties of biochar, such as yield, ash, specific surface area, pore structure, type and number of functional groups, and cation exchange capacity such properties can also affect the potential of remediation heavy metals in soil. Pyrolysis, also known as the thermal decomposition of feedstock's (biomass residue) under oxygen-free conditions, is the most common method for preparing those materials [48]. The most important measures of biochar quality appear to be high adsorption and cation exchange capacities and low levels of mobile matter (tars, resins, and other short-lived compounds) [52]. A sustainable model of biochar production primarily uses waste biomass, such as green waste from municipal landscaping, forestry, or agriculture (for example, bagasse). The surface of biochars produced during pyrolysis at lower temperatures $\left(200-400^{\circ} \mathrm{C}\right)$ are rich in "oxygencontaining functional groups" that enable the creation of surface complexes between cations (e.g., $\mathrm{Cu}^{2+}, \mathrm{Ni}^{2+}, \mathrm{Cd}^{2+}$, $\mathrm{Pb}^{2+}$, and $\mathrm{Zn}^{2+}$ ) and the biochar surface [53]. This negative charge can also increase soil $\mathrm{pH}$ after biochar application to contaminated soils because the negative surface attracts hydrogen ions from the soil solution. A higher soil $\mathrm{pH}$ serves to further increase the sorption of metals from the solution because of the deprotonation of $\mathrm{pH}$-dependent cation exchange sites on soil surfaces [54], especially in acidic soils.

(iii). Reaction Mechanism of biochar with soil

The idea mentioned from the above dissection some reactions that occur within the application of biochar to soil pollution include ion exchange, physical adsorption, electrostatic interaction, precipitation, and complexion.

Ion Exchange

Ion exchange means the process those acidic oxygencontaining functional groups on the surface of biochar, such as carboxyl groups, carbonyl groups, and hydroxyl groups, can ionize $\mathrm{H}^{+}$or surface base ions such as $\mathrm{Na}^{+}, \mathrm{K}^{+}, \mathrm{Ca}^{2+}$, $\mathrm{Mg}^{2+}$, etc., to exchange with heavy metal ions or cationic organic Pollutants [55].

Electrostatic Interaction
Electrostatic interaction refers to the electrostatic adsorption between the surface charge of biochar and heavy metal ions. When the $\mathrm{pH}$ value of the solution is greater than the charge point of biochar (pHpzc), the negative charge on the surface of biochar and the heavy metal with positive charge causes electrostatic adsorption. Heavy metal ions with a positive charge on the surface of biochar combine with oxygen-containing functional groups such as carboxyl, carbonyl, and hydroxyl [56].

Precipitation

Mineral components in biochar, such as $\mathrm{CO}^{2-}, \mathrm{PO}^{3-}$, $\mathrm{SiO}^{4-}, \mathrm{Cl}^{-}, \mathrm{SO}_{4}^{2-}, \mathrm{SO}^{2-}$, and $\mathrm{OH}^{-}$, combine with heavy metal ions to form water-insoluble substances such as metal oxides, metal phosphates, and metal carbonates, which promote the adsorption and immobilization of heavy metals. According to [57] Believed that the adsorption of $\mathrm{Cu}, \mathrm{Zn}$, and $\mathrm{Cd}$ by fertilizer biochar was mainly attributed to the precipitation of $\mathrm{CO} 3{ }^{2-}$ and $\mathrm{PO} 4{ }^{3-}$, while the electron surface complexation via $-\mathrm{OH}$ groups or delocalized pi was less.

\section{Complexation}

The surface of biochars produced during pyrolysis at lower temperatures $\left(200-400^{\circ} \mathrm{C}\right)$ are rich in "oxygen-containing functional groups" that enable the creation of surface complexes between cations (e.g., $\mathrm{Cu}^{2+}, \mathrm{Ni}^{2+}, \mathrm{Cd}^{2+}, \mathrm{Pb}^{2+}$, and $\mathrm{Zn}^{2+}$ ) and the biochar surface [53]. Complexion refers to the interaction between oxygen-containing functional groups on the surface of biochar and heavy metals to form complexes, which could be fixed. [58] Studied the aluminum phytotoxicity of cow manure biochar to wheat and concluded that the adsorption of aluminum by biochar was mainly through the complexation of carboxyl group with $[\mathrm{Al}(\mathrm{OH})]^{2+}$ and Its monomer surface, rather than through the electrostatic attraction of $\mathrm{Al}^{3+}$ with negative charge sites. [59] Believed that the adsorption of oxytetracycline by biochar was mainly mediated by $\pi-\pi$ Interaction and metal bridge, with surface complexation as the main factor, and cationic exchange might exist.

\subsubsection{Biological Method of Remediation (Bioremediation)}

Bioremediation is defined as the use of biological mechanisms to terminate, transform, or immobilize environmental contaminants in order to protect potential sensitive receptors. One of the best examples of the Bioremediation method is Phytoremediation. Phytoremediation has also been called green remediation, botanic-remediation, agro-remediation, and vegetative remediation. It is the use of plants to partially or substantially remediate selected contaminants in contaminated soil, sludge, sediment, groundwater, surface water, and wastewater. It utilizes a variety of plant biological processes and the physical characteristics of plants to aid in site remediation. These plants have certain hyper-accumulation ability for the contaminants in the soil (accumulated mainly in the root or above the root). When the plants are ripe or reach certain enrichment levels of heavy metals, remove heavy metals in the contaminated soil layer thoroughly by harvesting, burning and curing plants or another method after uptake of plants 
that released into the atmosphere from high toxic nonvolatile contaminant to less toxic gas phase. The key to the method is to find suitable plants with a strong ability for heavy metal accumulation and tolerance. Now more than 400 species of such plants have been found in the world, and most of them belong to cruciferous, including the genus Brassica,
Alyssums, Zea mays, Salix spp, Medicago sativa and Thlaspi [60]. Phytoremediation incorporates a number of different methods that can lead to contaminant degradation, removal through accumulation, or immobilization. These mechanisms include phytoextraction, phytostabilization, Phytodegradation, Rhizofiltration and phytovolatilization.

Table 1. Summary of bioremediation processes that can either minimized or avoid contamination of heavy metal from different media.

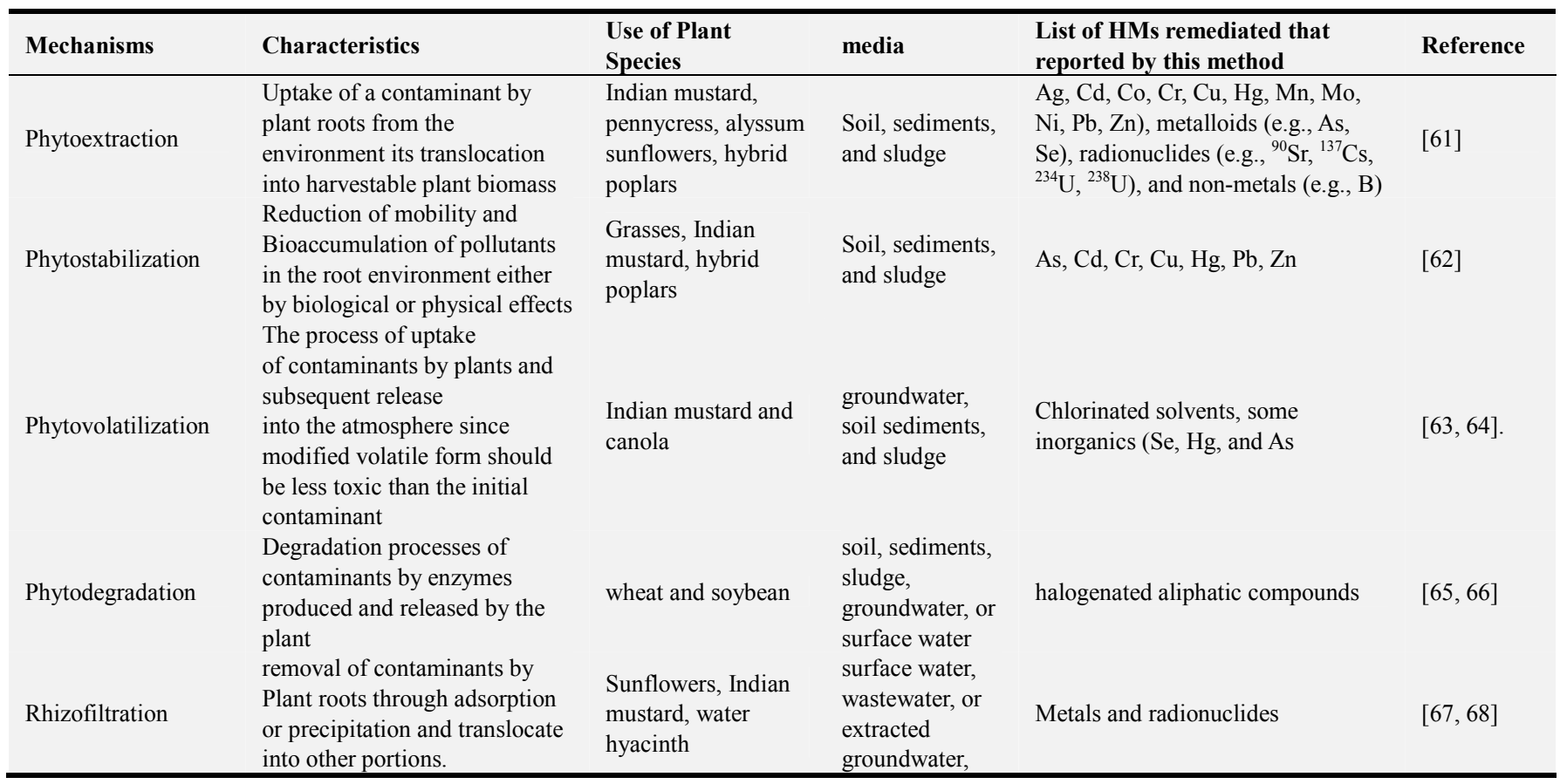

\subsubsection{The Physical Method of Remediation}

The remediation of soil by physical treatment includes technologies that separate the contaminants from the soil solids. The separation process is a volume reduction process that transfers the contaminant to another media, e.g., air or water, and collects it in a concentrated form. Depending on quantity and concentration, the new contaminated media may require further treatment. This additional treatment can either destroy the contaminant or concentrate it for recovery/reuse or ultimate disposal. Hence, physical separation treatment frequently leads to the need for a treatment train to complete the process. Physical treatment using separation technologies is done either in situ or physical adsorption. The main advantages of in situ treatment are that it allows the soil to be remediated without having to excavate or transport it. It also avoids land disposal restrictions on the re deposition of treated soil. In situ remediation generally involves longer treatment times. Because of the heterogeneity of the subsurface, it is also more difficult to assure uniformity of treatment. In situ treatment must also be concerned with avoiding the spread of contamination as a result of inducing the contaminants to move away from the zone of contaminated soil.

Physical Adsorption

The term adsorption is the change in concentration of a given substance at the interface as compared with the neighboring phases is referred to as adsorption. One of
Physical adsorption material is biochar utilizes its surface characteristics, namely porosity and large specific surface area, so that pollutants such as heavy metals or organic substances could be adsorbed on its surface or diffused into the microspores. The diameter of the heavy metal ions is smaller than the average pore diameter of the biochar. Generally, the smaller the diameter of the heavy metal, the more the pores penetrate into the pores of the biochar, thereby increasing the adsorption capacity [69]. The intensity of physical adsorption is closely related to the properties and specific surface area of biochar, the properties, and concentration of pollutants, and the temperature during adsorption process. Physical adsorption kinetics is usually fitted by pseudo-first-order and pseudo-second-order kinetic models [70]. Physical adsorption can be either single-layer adsorption or multi-layer adsorption, which is usually fitted by Langmuir and Freundlich model [71].

\section{Conclusion}

In this review paper understanding source of heavy metal, the influence of HMs on soil microorganism, plant growth and human health and different remediation mechanisms that prevent those effects were reviewed. The application of biochar in soil chemical reaction was listed. Different phytoremediation of heavy metal using different plant species was mentioned. Metal contaminated soil poses risks to 
humans and animals through the consumption of plants that have bio-accumulated toxic metals from contaminated soil. Effect of the contamination of heavy metal shows cyclic processes such problem can have overcome the contamination of heavy metal in soil utilizes like biochar, chelating agents and phytoremediation techniques. Biochar material derived from different by-products that have concurrently use remediation contaminated heavy metals in soil, ameliorating soil degradation processes, soil acidity and enhances productivity of crops.

\section{References}

[1] Melo, L. C., Puga, A. P., Coscione, A. R., Beesley, L., Abreu, C. A., \& Camargo, O. A. (2016). Sorption and desorption of cadmium and zinc in two tropical soils amended with sugarcane-straw-derived biochar. Journal of soils and sediments, 16 (1), 226-234.

[2] Morais, S., e Costa, F. G., \& de Lourdes Pereira, M. (2012). Heavy metals and human health. In Environmental HealthEmerging Issues and Practice. InTech.

[3] Duran, A., Tuzen, M., \& Soylak, M. (2008). Trace element levels in some dried fruit samples from Turkey. International Journal of Food Sciences and Nutrition, 59 (7-8), 581-589.

[4] Clemente, R., Pardo, T., Madejón, P., Madejón, E., \& Bernal, M. P. (2015). Food byproducts as amendments in trace elements contaminated soils. Food Research International, 73, 176-189.

[5] Wang J, Xia K, Waigi MG, Gao YZ, Odinga ES, Ling WT, Liu J. 2018. Application of biochar to soils may result in plant contamination and human cancer risk due to exposure of polycyclic aromatic hydrocarbons. Environment International 121 (1): 169-177.

[6] Garbisu C, Alkorta I. 2001. Phytoextraction: a cost-effective plant-based technology for the removal of metals from the environment. Bioresource Technology 77 (3): 229-236.

[7] Liu YX, Lonappan L, Brar SK, Yang SM. 2018. Impact of biochar amendment in agricul-tural soils on the sorption, desorption, and degradation of pesticides: a review. 2018. Science of the Total Environment 645: 60-70.

[8] Xu, R. K., \& Zhao, A. Z. (2013). Effect of biochars on adsorption of $\mathrm{Cu}$ (II), $\mathrm{Pb}$ (II) and $\mathrm{Cd}$ (II) by three variable charge soils from southern China. Environmental Science and Pollution Research, 20 (12), 8491-8501.

[9] Ansari, T. M., Marr, I. L., \& Tariq, N. (2004). Heavy metals in marine pollution perspective - a mini-review. Journal of Applied Sciences, 4 (1), 1-20.

[10] Draghici, C., Jelescu, C., Dima, C., Coman, G., \& Chirila, E. (2011). Heavy metals determination in environmental and biological samples. In Environmental Heavy Metal Pollution and Effects on Child Mental Development (pp. 145-158). Springer, Dordrecht.

[11] Chen, C. W., Chen, C. F., \& Dong, C. D. (2012). Distribution and accumulation of mercury in sediments of Kaohsiung River Mouth, Taiwan. APCBEE Procedia, 1, 153-158.

[12] Wuana R. A., Okieimen F. E. (2011). Heavy metals in contaminated soils: A review of sources.
[13] Flora, S. J. (2011). Arsenic-induced oxidative stress and its reversibility. Free Radical Biology and Medicine, 51 (2), $257-$ 281.

[14] Styblo, M., Del Razo, L. M., Vega, L., Germolec, D. R., LeCluyse, E. L., Hamilton, G. A., \& Thomas, D. J. (2000). Comparative toxicity of trivalent and pentavalent inorganic and methylated arsenicals in rat and human cells. Archives of toxicology, 74 (6), 289-299.

[15] Sharma, B., Singh, S., \& Siddiqi, N. J. (2014). Biomedical implications of heavy metals induced imbalances in redox systems. BioMed research international, 2014.

[16] Shi, H., Shi, X., \& Liu, K. J. (2004). Oxidative mechanism of arsenic toxicity and carcinogenesis. Molecular and cellular biochemistry, 255 (1-2), 67-78.

[17] Hughes, M. F., Beck, B. D., Chen, Y., Lewis, A. S., \& Thomas, D. J. (2011). Arsenic exposure and toxicology: a historical perspective. Toxicological Sciences, 123 (2), 305332.

[18] Singh, N., Kumar, D., \& Sahu, A. P. (2007). Arsenic in the environment: effects on human health and possible prevention. Journal of Environmental Biology, 28 (2), 359.

[19] Hopenhayn, C. (2006). Arsenic in drinking water: impact on human health. Elements, 2 (2), 103-107.

[20] Karrari, P., Mehrpour, O., \& Abdollahi, M. (2012). A systematic review on the status of lead pollution and toxicity in Iran; Guidance for preventive measures. DARU Journal of Pharmaceutical Sciences, 20 (1), 2.

[21] Malekirad, A. A., Oryan, S., Fani, A., Babar, V., Hashemi, M., Baeeri, M., ... \& Abdollahi, M. (2010). Study on clinical and biochemical toxicity biomarkers in zinc-lead mine workers. Toxicology and industrial health, 26 (6), 331-337.

[22] Jalali, M., \& Khanlari, Z. V. (2008). Environmental contamination of $\mathrm{Zn}, \mathrm{Cd}, \mathrm{Ni}, \mathrm{Cu}$, and $\mathrm{Pb}$ from industrial areas in Hamadan Province, western Iran. Environmental Geology, 55 (7), 1537-1543.

[23] Parizanganeh, A., Hajisoltani, P., \& Zamani, A. (2010). Assessment of heavy metal pollution in surficial soils surrounding Zinc Industrial Complex in Zanjan-Iran. Procedia Environmental Sciences, 2, 162-166.

[24] Gulson, B. L., Mizon, K. J., Korsch, M. J., Palmer, J. M., \& Donnelly, J. B. (2003). Mobilization of lead from human bone tissue during pregnancy and lactation - a summary of long-term research. Science of the Total Environment, 303 (1-2), 79-104.

[25] Yongsheng, Q. (2008). Study on the influences of combined pollution of heavy metals $\mathrm{Cu}$ and $\mathrm{Pb}$ on soil respiration. Journal of Anhui Agricultural Sciences, 36 (3), 1117.

[26] Jones, L. H. P., \& Jarvis, S. C. (1981). The fate of heavy metals. The chemistry of soil processes, 599.

[27] Boyd, R. S. (2010). Heavy metal pollutants and chemical ecology: exploring new frontiers. Journal of chemical ecology, $36(1), 46-58$.

[28] Satarug, S., Baker, J. R., Urbenjapol, S., Haswell-Elkins, M., Reilly, P. E., Williams, D. J., \& Moore, M. R. (2003). A global perspective on cadmium pollution and toxicity in the nonoccupationally exposed population. Toxicology Letters, 137 (1-2), 65-83. 
[29] McLaughlin, M. J., Hamon, R. E., McLaren, R. G., Speir, T. W., \& Rogers, S. L. (2000). A bioavailability-based rationale for controlling metal and metalloid contamination of agricultural land in Australia and New Zealand. Soil Research, 38 (6), 1037-1086.

[30] Basta, N. T., Ryan, J. A., \& Chaney, R. L. (2005). Trace element chemistry in residual-treated soil. Journal of environmental quality, 34 (1), 49-63.

[31] Sumner, M. E. (2000). Beneficial use of effluents, wastes, and biosolids. Communications in Soil Science and Plant Analysis, 31 (11-14), 1701-1715.

[32] Chaney, R. L., \& Oliver, D. P. (1996). Sources, potential adverse effects, and remediation of agricultural soil contaminants. In Contaminants and the soil environment in the Australasia-Pacific region (pp. 323-359). Springer, Dordrecht.

[33] Canet, R., Pomares, F., Tarazona, F., \& Estela, M. (1998). Sequential fractionation and plant availability of heavy metals as affected by sewage sludge applications to the soil. Communications in soil science and plant analysis, 29 (5-6), 697-716.

[34] Mattigod, S. V., \& Page, A. L. (1983). Assessment of metal pollution in soils. Applied environmental geochemistry, 355394.

[35] Bjuhr, J. (2007). Trace metals in soils irrigated with wastewater in a periurban area downstream Hanoi City, Vietnam.

[36] Smith, L. A. (1995). Remedial options for metalscontaminated sites. Lewis Publ.

[37] Djingova, R., \& Kuleff, I. (2000). Instrumental techniques for trace analysis. In Trace Metals in the Environment (Vol. 4, pp. 137-185). Elsevier.

[38] Jadia, C. D., \& Fulekar, M. H. (2009). Phytoremediation of heavy metals: recent techniques. African journal of biotechnology, 8 (6).

[39] Taiz, L., \& Zeiger, E. (2002). Plant physiology., 3rd edn. (Sinauer Associates: Sunderland, MA, USA).

[40] Schaller, A., \& Diez, T. (1991). Plant specific aspects of heavy metal uptake and comparison with quality standards for food and forage crops. Der Einfluß von festen Abfällen auf Böden, Pflanzen, 92-125.

[41] Bhagure, G. R., \& Mirgane, S. R. (2011). Heavy metal concentrations in groundwaters and soils of the Thane Region of Maharashtra, India. Environmental monitoring and assessment, 173 (1-4), 643-652.

[42] Arora, M., Kiran, B., Rani, S., Rani, A., Kaur, B., \& Mittal, N. (2008). Heavy metal accumulation in vegetables irrigated with water from different sources. Food Chemistry, 111 (4), 811815 .

[43] Al-Othman, Z. A., \& Naushad, M. (2011). Organic-inorganic type composite cation exchanger poly-o-toluidine $\mathrm{Zr}$ (IV) tungstate: preparation, physicochemical characterization and its analytical application in separation of heavy metals. Chemical engineering journal, 172 (1), 369-375.

[44] Shakeri, A., Moore, F., \& Modabberi, S. (2009). Heavy metal contamination and distribution in the Shiraz industrial complex zone soil, South Shiraz, Iran. World Applied
Sciences Journal, 6 (3), 413-425.

[45] Q. X. Zhou and Y. F. Song "Remediation of Contaminated Soils: Principles and Methods," Science Press, 7, 345-346, 2004

[46] Namgay, T., Singh, B., \& Singh, B. P. (2010). Influence of biochar application to soil on the availability of $\mathrm{As}, \mathrm{Cd}, \mathrm{Cu}$, $\mathrm{Pb}$, and $\mathrm{Zn}$ to maize (Zea mays L.). Soil Research, 48 (7), 638-647.

[47] Maia, C. M. B., Madari, B. E., \& Novotny, E. H. (2011). Advances in biochar research in Brazil. Embrapa SolosArtigoemperiódicoindexado (ALICE).

[48] Lehmann, J. (2007). Bio-energy in the black. Frontiers in Ecology and the Environment, 5 (7), 381-387.

[49] Major, J., Rondon, M., Molina, D., Riha, S. J., \& Lehmann, J. (2010). Maize yield and nutrition during 4 years after biochar application to a Colombian savanna oxisol. Plant and soil, 333 (1-2), 117-128.

[50] Zhang, A., Bian, R., Pan, G., Cui, L., Hussain, Q., Li, L., \& $\mathrm{Yu}, \mathrm{X}$. (2012). Effects of biochar amendment on soil quality, crop yield and greenhouse gas emission in a Chinese rice paddy: a field study of 2 consecutive rice growing cycles. Field Crops Research, 127, 153-160.

[51] Novak, J. M., Busscher, W. J., Laird, D. L., Ahmedna, M., Watts, D. W., \& Niandou, M. A. (2009). Impact of biochar amendment on fertility of a southeastern coastal plain soil. Soil science, 174 (2), 105-112.

[52] McLaughlin, H., Anderson, P. S., Shields, F. E., \& Reed, T. B. (2009, August). All biochars are not created equal, and how to tell them apart. In Proceedings, North American Biochar Conference, Boulder, Colorado (pp. 1-36).

[53] Uchimiya, M., Chang, S., \& Klasson, K. T. (2011). Screening biochars for heavy metal retention in soil: the role of oxygen functional groups. Journal of Hazardous Materials, 190 (1-3), 432-441.

[54] Rees, F., Simonnot, M. O., \& Morel, J. L. (2014). Short-term effects of biochar on soil heavy metal mobility are controlled by intra-particle diffusion and soil $\mathrm{pH}$ increase. European Journal of Soil Science, 65 (1), 149-161.

[55] Hassan, M. M.; Carr, C. M. A critical review on recent advancements of the removal of reactive dyes from dyehouse effluent by ion-exchange adsorbents. Chemosphere 2018, 209, 201-219.

[56] Pan, J.; Jiang, J.; Xu, R. Adsorption of Cr (III) from acidic solutions by crop straw derived biochars. J. Environ. Sci. 2013, $25,1957-1965$.

[57] Xu, X.; Cao, X.; Zhao, L.; Wang, H.; Yu, H.; Gao, B. Removal of $\mathrm{Cu}, \mathrm{Zn}$, and $\mathrm{Cd}$ from aqueous solutions by the dairy manure-derived biochar. Environ. Sci. Pollut. Res. 2013, $20,358-368$.

[58] Qian, L.; Chen, B.; Hu, D. Effective Alleviation of Aluminum Phytotoxicity by Manure-Derived Biochar. Environ. Sci. Technol. 2013, 47, 2737-2745.

[59] Jia, M.; Wang, F.; Bian, Y.; Jin, X.; Song, Y.; Kengara, F. O.; $\mathrm{Xu}, \mathrm{R}$; J Jiang, $\mathrm{X}$. Effects of $\mathrm{pH}$ and metal ions on oxytetracycline sorption to maize-straw-derived biochar. Bioresour. Technol. 2013, 136, 87-93. 
[60] Xin QG, Pan WB, Zhang TP. (2003). On phytoremediation of heavy metal contaminated soils. Ecologic Science, 22 (3): 275-279.

[61] Bañuelos, G. S., M. C. Shannon, H. Ajwa, J. H. Draper, J. Jordahl, and L. Licht. 1999. Phytoextraction and accumulation of boron and selenium by poplar (Populus) hybrid clones. Int. J. Phytoremediation. 1 (1): 81-96.

[62] U. S. EPA. 1997. Status of in situ phytoremediation technology. pp. 31-42. Recent developments for in situ treatment of metal contaminated soils. March. EPA-542-R-97004 .

[63] Adler, T. 1996. Botanical cleanup crews. Sci. News. 150: $42-$ 43.

[64] Bañuelos, G. S., H. A. Ajwa, B. Mackey, L. L. Wu, C. Cook, S. Akohoue, and S. Zambrzuski. 1997. Evaluation of different plant species used for phytoremediation of high soil selenium. J. Environ. Qual. 26 (3): 639-646.

[65] Newman, L. A., S. L. Doty, K. L. Gery, P. E. Heilman, I. Muiznieks, T. Q. Shang, S. T. Siemieniec, S. E. Strand, X. Wang, A. M. Wilson, and M. P. Gordon. 1998. Phytoremediation of organic contaminants: A review of phytoremediation research at the University of Washington. J. Soil Contam. 7 (4): 531-542.
[66] Wilken, A., C. Bock, M. Bokern, and H. Harms. 1995. Metabolism of different PCB congeners in plant cell cultures. Environ. Toxicol. Chem. 14 (12): 2017-2022.

[67] Dushenkov, V., P. B. A. Nanda Kumar, H. Motto, and I. Raskin. 1995. Rhizofiltration: The use of plants to remove heavy metals from aqueous streams. Environ. Sci. Technol.

[68] Dushenkov, S., D. Vasudev, Y. Kapulnik, D. Gleba, D. Fleisher, K. C. Ting, and B. Ensley. 1997. Removal of uranium from water using terrestrial plants. Environ. Sci. Technol. 31 (12): 3468-3474.

[69] Ngah, W. W.; Hanafiah, M.; Hanafiah, M. A. K. M. Removal of heavy metal ions from wastewater by chemically modified plant wastes as adsorbents: A review. Bioresour. Technol. 2008, 99, 3935-3948.

[70] Sar1, A.; Tuzen, M. Kinetic and equilibrium studies of biosorption of $\mathrm{Pb}$ (II) and $\mathrm{Cd}$ (II) from aqueous solution by macrofungus (Amanita rubescens) biomass. J. Hazard. Mater. 2009, 164, 1004-1011.

[71] Qiu, Y.; Xiao, X.; Cheng, H.; Zhou, Z.; Sheng, G. D. Influence of Environmental Factors on Pesticide Adsorption by Black Carbon: $\mathrm{pH}$ and Model Dissolved Organic Matter. Environ. Sci. Technol. 2009, 3, 4973-4978. 